\title{
Chemical Compounds, Physicochemical Properties, and Antioxidant Activity of A. cardamomum Leaves and Rhizomes Oils on Different Distillation Time
}

\author{
Rini Pujiarti and Aisyah Kusumadewi
}

\begin{abstract}
Amomum cardamomum is local cardamom that grows widely and recently developed as an agroforestry crop in Indonesia. Its seeds, leaves and rhizomes are sources of essential oil. Essential oils from cardamom have many benefits for health and flavouring agent. The objectives of this study were to elucidate the yield, chemical composition, physico-chemical properties, and antioxidant activities of leaves and rhizomes oils of cardamom distillated using water-steam distillation for 4, 6, and 8 hours. The chemical composition were analyzed by GC-MS, physicochemical properties were analyzed using ISO standard and antioxidant activity were analyzed by DPPH method. The results showed that $A$. cardamomum oils yield between $0.06-0.33 \%$. The main compound in the oils is 1,8 -cineole with the highest percentage was obtained from cardamom rhizomes oil distillated for 6 hours $(60.63 \%)$. The results of each sample almost have the same quality with specific gravity between $0.899-0.909$; refractive index between 1.476-1.478; optical rotation between $(+) 2.05^{\circ}-(+) 2.38^{\circ}$; miscibility in $70 \%$ alcohol between 1:7-1:9; and acid number between 0.49-0.69. The leaves and rhizomes oils of $A$. cardamomum showed potent antioxidant activity with the highest antioxidant were obtained from cardamom rhizomes oil distillated for 8 hours with $\mathrm{IC}_{50}: 0.039 \mathrm{~g} / \mathrm{ml}$.
\end{abstract}

Keywords: distillation time, cardamom oils, leaf, rhizome, chemical composition, physico-chemical properties, antioxidant

\section{Introduction}

There are two types of cardamom that are grown in Indonesia namely Amomum cardamomum (local cardamom) and Elettaria cardamomum (cardamom sabrang) (Suryadinata 2008). A. cardamomum is native to Indonesia, endemic to the mountainous areas in western Java. This species is commonly cultivated in Western Java, Southern Sumatra, and Moluccas whereas Java and Sumatra are the major growing areas (Lim 2013).

A. cardamomum is a crop that widely cultivated in Indonesia, because of high economic value, suitable growing site, and can grow well under forest stands. Agroforestry between forest plants and cardamom began to be widely developed in Indonesia such in Ciamis, West Java. Cardamom agroforestry is profiting the farmers by 5.7 times more compared to the rainfed agriculture. In the mountainous area, agroforestry is also a favorite land management system. The implementation of cardamom agroforestry in large scale land use is quite promising for economic and ecological sustainability (Sharma et al. 2007). Part of cardamom plant that is generally used to produce essential oil is seed, while the leaves and rhizome cardamom has not been widely utilized. In fact, leaves and rhizome of cardamom can also produce essential oils (Winarsi 2014).

Essential oils may be extracted from different parts of the plant, such as leaves, fruit peels, seeds, bark, wood wicks, and flowers, and are usually obtained from steam or hydrodistillation (Ahn et al. 2018). Essential oil of cardamom can obtained by hydrodistillation with distillation time of about 6-8 hours. Cardamom plant produces an optimal seed up to the age of 10-15 years, after that the plants need to be replaced with the new plants. This condition causes the leaves and the rhizomes become waste. Previous study on cardamom provide a high yield $(2.43 \%)$ from leaves oil of Elletaria cardamomum compared to other plants of the Zingiberaceae family (Batubara et al. 2016a). While research on the influence of distilation time on yield of cardamom seed oil showed that distillation times give different yield and quality (Rosjidi 1993).

Essential oils have been used in traditional medicine. The availabilities of essential oils seem to have a great potential as anti-inflammatory, anti-bacterial, anti-cancer therapeutic agents, and aromatherapies. In recent years, the essential oils and herbal extracts have attracted a great deal of scientific interest due to their potential as a source of natural antioxidants and biologically active compounds (Bozin et al. 2006; Tepe et al. 2005; Shaaban et al. 2011; Perricone et al. 2015).

Seed of cardamom known as queen of spices (Charles and Denys 2013) while cardamom essential oils have some bioactivities such as fever medicine, gout drug, and heartburn medicine. On the other hand, seeds, leaves, and cardamom rhizome also contain essential oils and compounds such as saponins, flavonoids, and polyphenols that have a potential as antioxidants (Winarsi 2014). Antioxidant activity also can be found in essential oils from Ellettaria cardamomum leaves (Batubara et al. 2016b). Antioxidant has been widely discussed for medical purposes, because its compounds can prevent the reaction caused by the presence of free radicals. To reduce the damage caused by reactive compounds, additive substances with antioxidant activity such as butylated 
hydroxyl anisole (BHA) and butylated hydroxyl toluene $(\mathrm{BHT})$ are widely used as drug compounds. However, It potentially toxic because they are made from chemicals. Therefore, natural antioxidants are in demand because they use natural ingredients, making it safer than synthetic materials. Natural antioxidant can be obtained from essential oils (Pujiarti et al. 2015), such as from cardamom oil (Wang et al. 2017).

Previous studies have analyzed some cardamom essential oils from seed. However, study of leaves and rhizomes $A$. cardamomum essential oils and hydrodistillation time are still limited. This study were conducted to elucidate the yield, chemical composition, physico-chemical properties, and antioxidant of leaves and rhizomes of $A$. cardamomum oils that were extracted from different times hydrodistillation of 4,6 , and 8 hours.

\section{Materials and Methods}

\section{Plant Material and Extraction}

Fresh leaves and rhizomes of Amomum cardamomum (age 11 years old) were collected from Prangkokan village in Kulonprogo district, Yogyakarta, Indonesia. The cardamom leaves and rhizomes were chopped with a length of $2 \mathrm{~cm}$. For each sample, $5 \mathrm{~kg}$ of fresh cardamom leaves and rhizomes were extracted by hydrodistillation (watersteam distillation) for 4,6 , and 8 hours. Essential oil extraction was carried out by a hydrodistillation using $5 \mathrm{~kg}$ capacity. The obtained oils were kept in labeled bottles and were stored in fridge before analyzed.

\section{Essential Oil Yield}

The oil yields were determined based on dried weight of leaves or rhizomes. The $2 \mathrm{~g}$ fresh cardamom leaves and rhizomes were oven-dried each at $103 \pm 2^{\circ} \mathrm{C}$ until its weight constant and water content were calculated.

\section{GC-MS Analysis}

The chemical compositions of cardamom oils were analyzed by GC-MS (Gas Chromatography-Mass Spectrometry) QP2010S with Agilent HP 5 column with length $30 \mathrm{~m}$ and film thickness $0.25 \mathrm{~nm}$. The carrier gas was Helium and ionizing El $70 \mathrm{eV}$. The oven column temperature was set at $70^{\circ} \mathrm{C}$ and the injection temperature was set to $310^{\circ} \mathrm{C}$. The chemical analysis was performed on each sample. GC-MS analysis was performed with retention time 50 minutes. Quantification compounds of cardamom oils were calculated based on the relative peak area (percent area) from chromatogram and chemical components were confirmed by comparing retention time with NIST 147 data base library.

\section{Physico-chemical Properties}

Physico-chemical properties of cardamom oils was analyzed based on ISO 4733: 1981 including specific gravity, refractive index, optical rotation, miscibility in $70 \%$ alcohol, and acid numbers on each sample. The specific gravity was analyzed using pycnometer with certain temperature of $20^{\circ} \mathrm{C}$. The refractive index was analyzed using hand-refractometer. The optical rotation was analyzed using polarimeter for samples and a control (distilled water). The acid number was analyzed by $\mathrm{NaOH} 0.1 \mathrm{~N}$ titration.

\section{Antioxidant Activity}

Antioxidant activity was analyzed by DPPH method (1,1diphenyl-2-picrilhidrazil) based on Molyneux (2004) method with slight modification. Antioxidant activity test used 4 oil concentrations of $0.05 \mathrm{~g} / \mathrm{ml}, 0.1 \mathrm{~g} / \mathrm{ml}, 0.15 \mathrm{~g} / \mathrm{ml}$, and $0.2 \mathrm{~g} / \mathrm{ml}$. Tests were performed on each sample. The antioxidant percentages were analyzed by spectrometer (WPA brand) number at $515 \mathrm{~nm}$ wavelength. The inhibitory concentration $50 \%\left(\mathrm{IC}_{50}\right)$ antioxidant of cardamom oils were determined by probit regression.

\section{Statistical Analysis}

All tests and analyses had been done in three replications on each sample. The results were tested by Completely Randomized Design/CRD. Significant differences between means were determined by Tukey HSD analysis. $P<0.05$ was considered statistically significant.

\section{Results and Discussion}

The $A$. cardamomum leaves oils in this study have yield of between $0.26-0.33 \%$ and cardamom rhizomes oils had yield $0.06 \%$. The yield of $A$. cardamomum oil were obtained from distillation time of 4,6 ,and 8 hours were different, however the yield of leaves oils had tendency increasing by the increasing of distillation time. The highest yield of leaves oils were obtained from distillation time of 8 hours. On the other hand, distillation times 4,6, dan 8 hours gave no different yield of rhizomes oils. The yield of $A$. cardamomum leaves oils in this study lower than Elettaria cardamomum leaves oils (3.15\%) (Batubara et al. 2016b), this is probably due to the different species of cardamom leaves were used. Parts of the plant also have effect on the oil produced, rhizome tissue is thicker than leaf tissue of cardamom. The hydrofusion process that occurs becomes more difficult on the rhizomes, resulting in fewer oil yields. This result accordanced with the Jaafar et al. (2007) study about the essential oils of the leaf and rhizome of Etlingera elatior, where the leaf oil has higher yield $(0.0735 \%)$ than rhizome oil $(0.0021 \%)$. 
Table 1. Chemical composition of A. cardamomum essential oils

\begin{tabular}{|c|c|c|c|c|c|c|c|c|c|}
\hline \multirow{3}{*}{ No. } & \multirow{3}{*}{ Components* $^{*}$} & \multirow{3}{*}{$\begin{array}{c}\text { Molecular } \\
\text { Formula }\end{array}$} & \multirow{3}{*}{ Compound Group } & \multicolumn{6}{|c|}{ Percentage [\%] } \\
\hline & & & & \multicolumn{3}{|c|}{ Leaves } & \multicolumn{3}{|c|}{ Rhizome } \\
\hline & & & & $4 \mathrm{H}$ & $6 \mathrm{H}$ & $8 \mathrm{H}$ & $4 \mathrm{H}$ & $6 \mathrm{H}$ & $8 \mathrm{H}$ \\
\hline 1 & Alpha-Thujene & $\mathrm{C}_{10} \mathrm{H}_{16}$ & Monoterpenes & - & - & - & 5.66 & 12.1 & 13.3 \\
\hline 2 & 4-Carene & $\mathrm{C}_{10} \mathrm{H}_{16}$ & Monoterpenes & 0.6 & - & - & - & - & - \\
\hline 3 & M-Cymene & $\mathrm{C}_{10} \mathrm{H}_{14}$ & Monoterpenes & 28.5 & 32.5 & 30.2 & 13.3 & 16.5 & 16.7 \\
\hline 4 & 1,8-Cineole & $\mathrm{C}_{10} \mathrm{H}_{18} \mathrm{O}$ & $\begin{array}{l}\text { Oxygenated } \\
\text { Monoterpenes }\end{array}$ & 55.1 & 52.2 & 50.3 & 51 & 61 & 51 \\
\hline 5 & Alpha-Terpinene & $\mathrm{C}_{10} \mathrm{H}_{16}$ & Monoterpenes & - & - & - & - & - & 0.56 \\
\hline 6 & Beta-Linalool & $\mathrm{C}_{10} \mathrm{H}_{18} \mathrm{O}$ & $\begin{array}{l}\text { Oxygenated } \\
\text { Monoterpenes }\end{array}$ & - & - & - & - & - & - \\
\hline 7 & Linalool & $\mathrm{C}_{10} \mathrm{H}_{18} \mathrm{O}$ & $\begin{array}{l}\text { Oxygenated } \\
\text { Monoterpenes }\end{array}$ & - & - & - & - & 3.3 & 3.38 \\
\hline 8 & Cyclohexane-I-ol & $\mathrm{C}_{10} \mathrm{H}_{16} \mathrm{O}$ & $\begin{array}{l}\text { Oxygenated } \\
\text { Monoterpenes }\end{array}$ & 0.26 & - & - & - & - & - \\
\hline 9 & Alpha-Terpineol & $\mathrm{C}_{10} \mathrm{H}_{18} \mathrm{O}$ & $\begin{array}{l}\text { Oxygenated } \\
\text { Monoterpenes }\end{array}$ & - & - & - & - & 0.57 & 2.56 \\
\hline 10 & Limonene oxide & $\mathrm{C}_{10} \mathrm{H}_{16} \mathrm{O}$ & $\begin{array}{l}\text { Oxygenated } \\
\text { Monoterpenes }\end{array}$ & - & - & - & - & - & 0.52 \\
\hline 11 & Terpineol & $\mathrm{C}_{10} \mathrm{H}_{18} \mathrm{O}$ & $\begin{array}{l}\text { Oxygenated } \\
\text { Monoterpenes }\end{array}$ & 0.18 & - & - & - & - & - \\
\hline 12 & Sabinenehydrate & $\mathrm{C}_{10} \mathrm{H}_{18} \mathrm{O}$ & $\begin{array}{l}\text { Oxygenated } \\
\text { Monoterpenes }\end{array}$ & - & - & - & 0.9 & 0.96 & 0.81 \\
\hline 13 & Alpha-Terpineol acetate & $\mathrm{C}_{12} \mathrm{H}_{20} \mathrm{O}_{2}$ & Hydrocarbon & - & - & - & 1.37 & - & - \\
\hline 14 & Cyclohexene & $\mathrm{C}_{10} \mathrm{H}_{18} \mathrm{O}$ & $\begin{array}{l}\text { Oxygenated } \\
\text { Monoterpenes }\end{array}$ & - & - & 0.34 & - & - & - \\
\hline 15 & P-menth-1-en8-ol & $\mathrm{C}_{10} \mathrm{H}_{18} \mathrm{O}$ & $\begin{array}{l}\text { Oxygenated } \\
\text { Monoterpenes }\end{array}$ & 0.31 & - & - & - & - & - \\
\hline 16 & Alpha-Thujenal & $\mathrm{C}_{10} \mathrm{H}_{14} \mathrm{O}$ & $\begin{array}{l}\text { Oxygenated } \\
\text { Monoterpenes }\end{array}$ & - & - & - & - & 0.47 & - \\
\hline 17 & Azulenemethanol & $\mathrm{C}_{15} \mathrm{H}_{26} \mathrm{O}$ & $\begin{array}{l}\text { Oxygenated } \\
\text { Sesquiterpenes }\end{array}$ & - & - & - & - & - & 0.37 \\
\hline 18 & Sabinyl acetate & $\mathrm{C}_{12} \mathrm{H}_{18} \mathrm{O}_{2}$ & Hydrocarbon & - & - & - & - & 0.48 & - \\
\hline 19 & Isosafrole & $\mathrm{C}_{10} \mathrm{H}_{10} \mathrm{O}_{2}$ & $\begin{array}{l}\text { Oxygenated } \\
\text { Monoterpenes }\end{array}$ & - & - & - & 1.38 & 0.57 & - \\
\hline 20 & Thymol & $\mathrm{C}_{10} \mathrm{H}_{14} \mathrm{O}$ & $\begin{array}{l}\text { Oxygenated } \\
\text { Monoterpenes }\end{array}$ & - & - & - & - & - & 0.72 \\
\hline 21 & Isothujol & $\mathrm{C}_{10} \mathrm{H}_{18} \mathrm{O}$ & $\begin{array}{l}\text { Oxygenated } \\
\text { Monoterpenes }\end{array}$ & - & - & 0.21 & 0.76 & - & - \\
\hline 22 & Limonene epoxide & $\mathrm{C}_{10} \mathrm{H}_{16} \mathrm{O}$ & $\begin{array}{l}\text { Oxygenated } \\
\text { Monoterpenes }\end{array}$ & - & - & 0.16 & - & - & - \\
\hline 23 & Acetamide, N-prophyl & $\mathrm{C}_{15} \mathrm{H}_{11} \mathrm{NO}$ & Carboxamide & - & 0.41 & & - & 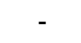 & \\
\hline 24 & Patchoulene & $\mathrm{C}_{15} \mathrm{H}_{24}$ & Sesquiterpenes & 10.9 & 11.1 & 0.12 & 1.69 & 1.36 & 0.61 \\
\hline 25 & Chamigrene & $\mathrm{C}_{15} \mathrm{H}_{24}$ & Sesquiterpenes & 0.36 & - & - & 14 & - & - \\
\hline 26 & Octahydronapthalene & $\mathrm{C}_{15} \mathrm{H}_{24}$ & Sesquiterpenes & - & - & - & 1.05 & - & - \\
\hline 27 & Thujopsene & $\mathrm{C}_{15} \mathrm{H}_{24}$ & Sesquiterpenes & - & 0.63 & 0.37 & - & - & 0.75 \\
\hline 28 & Beta-Humulene & $\mathrm{C}_{15} \mathrm{H}_{24}$ & Sesquiterpenes & 0.17 & - & - & - & - & - \\
\hline 29 & Napthalene & $\mathrm{C}_{15} \mathrm{H}_{24}$ & Sesquiterpenes & - & - & 0.12 & - & - & 3.74 \\
\hline 30 & Beta-Vatirenene & $\mathrm{C}_{15} \mathrm{H}_{22}$ & Sesquiterpenes & 0.57 & - & 0.67 & 1.71 & - & \\
\hline 31 & $\begin{array}{l}\text { Cycloisolongifolene,8,9- } \\
\text { dehydro }\end{array}$ & $\mathrm{C}_{15} \mathrm{H}_{22}$ & Sesquiterpenes & 0.29 & 0.84 & - & - & - & - \\
\hline 32 & Beta-Chamigrene & $\mathrm{C}_{15} \mathrm{H}_{24}$ & Sesquiterpenes & - & - & 12.8 & - & - & \\
\hline 33 & Alpha-Bisabolene & $\mathrm{C}_{15} \mathrm{H}_{24}$ & Sesquiterpenes & - & - & 0.36 & 1.25 & 0.46 & 0.77 \\
\hline 34 & Cyclohexane & $\mathrm{C}_{15} \mathrm{H}_{24}$ & Sesquiterpenes & 0.23 & - & - & - & - & - \\
\hline 35 & Alpha-Panasinsen & $\mathrm{C}_{15} \mathrm{H}_{24}$ & Sesquiterpenes & 1.73 & 1.68 & 1.9 & - & - & - \\
\hline 36 & Germacrene & $\mathrm{C}_{15} \mathrm{H}_{24}$ & Sesquiterpenes & - & - & - & - & - & 2.85 \\
\hline 37 & Methanoazulen & $\mathrm{C}_{15} \mathrm{H}_{24} \mathrm{O}$ & $\begin{array}{l}\text { Oxygenated } \\
\text { Sesquiterpenes }\end{array}$ & - & - & 0.22 & - & - & - \\
\hline 38 & Gamma-Gurjunepoxide & $\mathrm{C}_{15} \mathrm{H}_{24} \mathrm{O}$ & $\begin{array}{l}\text { Oxygenated } \\
\text { Sesquiterpenes }\end{array}$ & - & - & - & 0.87 & - & \\
\hline $\begin{array}{l}39 \\
40\end{array}$ & $\begin{array}{l}\text { Cedrene } \\
\text { Aromadendrene }\end{array}$ & $\mathrm{C}_{15} \mathrm{H}_{24}$ & Sesquiterpenes & - & - & 0.21 & - & 0.55 & \\
\hline 40 & Aromadendrene & $\mathrm{C}_{15} \mathrm{H}_{22}$ & Sesquiterpenes & - & - & 0.36 & - & & \\
\hline
\end{tabular}




\begin{tabular}{|c|c|c|c|c|c|c|c|c|c|}
\hline 41 & Lanceol & $\mathrm{C}_{15} \mathrm{H}_{24} \mathrm{O}$ & $\begin{array}{l}\text { Oxygenated } \\
\text { Monoterpenes }\end{array}$ & - & - & 0.39 & 0.96 & - & - \\
\hline 42 & Spathulenol & $\mathrm{C}_{15} \mathrm{H}_{24} \mathrm{O}$ & $\begin{array}{l}\text { Oxygenated } \\
\text { Sesquiterpenes }\end{array}$ & 0.27 & - & - & - & - & - \\
\hline 43 & Cycloprop[e]azulene & $\mathrm{C}_{15} \mathrm{H}_{24}$ & Sesquiterpenes & & - & 1.08 & - & - & - \\
\hline 44 & Azulene & $\mathrm{C}_{15} \mathrm{H}_{24}$ & $\begin{array}{l}\text { Sesquiterpenes } \\
\text { Oxyaenated }\end{array}$ & 0.63 & - & - & - & - & - \\
\hline 45 & Globulol & $\mathrm{C}_{15} \mathrm{H}_{26} \mathrm{O}$ & $\begin{array}{l}\text { Oxygenated } \\
\text { Sesquiterpenes }\end{array}$ & - & 0.62 & - & - & 0.48 & - \\
\hline 46 & Alpha-Bisabolene epoxide & $\mathrm{C}_{15} \mathrm{H}_{24} \mathrm{O}$ & $\begin{array}{l}\text { Oxygenated } \\
\text { Sesquiterpenes }\end{array}$ & - & - & 0.17 & - & - & - \\
\hline 47 & Ledol & $\mathrm{C}_{15} \mathrm{H}_{26} \mathrm{O}$ & $\begin{array}{l}\text { Oxygenated } \\
\text { Monoterpenes }\end{array}$ & - & - & - & - & 0.63 & - \\
\hline 48 & Bergamotol & $\mathrm{C}_{15} \mathrm{H}_{24} \mathrm{O}$ & $\begin{array}{l}\text { Oxygenated } \\
\text { Sesquiterpenes }\end{array}$ & - & - & - & 0.91 & - & - \\
\hline $\begin{array}{l}49 \\
50\end{array}$ & $\begin{array}{l}\text { Dibutyl phthalate } \\
\text { Dimethyl ester }\end{array}$ & $\begin{array}{l}\mathrm{C}_{16} \mathrm{H}_{22} \mathrm{O}_{4} \\
\mathrm{C}_{16} \mathrm{H}_{24} \mathrm{O}_{6}\end{array}$ & $\begin{array}{l}\text { Hydrocarbon } \\
\text { Hydrocarbon }\end{array}$ & $\begin{array}{l}- \\
-\end{array}$ & $\begin{array}{l}- \\
-\end{array}$ & $\begin{array}{l}- \\
-\end{array}$ & $\begin{array}{c}0.98 \\
-\end{array}$ & $\begin{array}{c}0.63 \\
-\end{array}$ & $\begin{array}{l}1.12 \\
0.31\end{array}$ \\
\hline & & & Total & 100 & 100 & 100 & 100 & 100 & 100 \\
\hline
\end{tabular}

Note: * : Identification by Nist 147 library, - : not detected, $\mathrm{H}$ : distillation hour

GC-MS analysis showed that $A$. cardamomum oils consists of several compounds with different percentages in each sample. Chemical compounds of $A$. cardamomum essential oils showed in Table 1. The main compounds in $A$. cardamomum oils were obtained in this study are 1,8cineole (50.30-60.95\%) and m-cymene (13.29-32.54\%). Previous studies also found that 1,8 cineole is the main compound of $A$. cardamomum leaf oil (Riendyani 2014). Ketaren (1985) also stated that the cardamom oil has the main compound 1,8 cineole. In this study, cardamom leaves oils were distillated for 4 hours has the highest 1,8-cineole with percentage $55.11 \%$, while on the cardamom rhizomes oils were distillated for 6 hours oil has the highest 1,8cineole with percentage $60.95 \%$. Chemical compounds contained in leaves and rhizome of cardamom in this study are mostly included in the monoterpenes, oxygenated monoterpenes, and sesquiterpenes groups (Table 1).

Table 2. Physico-Chemical Properties of A. cardamomum Oils

\begin{tabular}{|c|c|c|c|c|c|}
\hline $\begin{array}{c}\text { Sample Oils } \\
\text { A. cardamomum }\end{array}$ & $\begin{array}{l}\text { Specific } \\
\text { Gravity } \\
\left(20^{\circ} \mathrm{C}\right)\end{array}$ & $\begin{array}{l}\text { Refractive Index } \\
\qquad\left(20^{\circ} \mathrm{C}\right)\end{array}$ & $\begin{array}{l}\text { Miscibility in } \\
\text { Alcohol 70\% }\end{array}$ & $\begin{array}{c}\text { Optical Rotation } \\
\left({ }^{\circ}\right)\end{array}$ & Acid Number \\
\hline Leaves oil - distillated for 4 hours & $0.903 \pm 0.03 a$ & $1.476 \pm 0.002 a$ & $1: 7.33 \pm 0.58 a$ & $(+) 2.37 \pm 0.09 a$ & $0.50 \pm 0.08 a$ \\
\hline Leaves oil -distillated for 6 hours & $0.906 \pm 0.02 a$ & $1.478 \pm 0.001 a$ & $1: 7.67 \pm 0.58 a$ & $(+) 2.14 \pm 0.13 a$ & $0.56 \pm 0.08 a$ \\
\hline Leaves oil -distillated for 8 hours & $0.909 \pm 0.03 a$ & $1.478 \pm 0.001 a$ & $1: 8.00 \pm 0.00 a$ & $(+) 2.05 \pm 0.05 a$ & $0.57 \pm 0.12 a$ \\
\hline Rhizomes oil- distillated for 4 hours & $0.899 \pm 0.00 a$ & $1.476 \pm 0.002 a$ & $1: 7.67 \pm 0.58 a$ & $(+) 2.38 \pm 0.02 a$ & $0.49 \pm 0.09 a$ \\
\hline Rhizomes oil- distillated for 6 hours & $0.901 \pm 0.01 \mathrm{a}$ & $1.477 \pm 0.002 a$ & $1: 8.00 \pm 0.00 a$ & $(+) 2.28 \pm 0.13 a$ & $0.59 \pm 0.07 a$ \\
\hline Rhizomes oil- distillated for 8 hours & $0.902 \pm 0.01 \mathrm{a}$ & $1.478 \pm 0.001 \mathrm{a}$ & $1: 8.33 \pm 0.58 a$ & $(+) 2.24 \pm 0.17 a$ & $0.69 \pm 0.02 a$ \\
\hline ISO 4733:1981* & $0.191-0.938$ & $1.462-1.468$ & $1: 2-1: 5$ & $22-41$ & Max. 6 \\
\hline
\end{tabular}

( ${ }^{*}$ Source : ISO 4733:1981)

Note : identical letters $(a, b$, etc.) mean no significant difference between mean in same column at $P<0.05$

Physicochemical properties of each sample were analyzed in this study almost had the same qualities and values. Statistical analysis showed no significant difference for each sample. The physicochemical properties of $A$. Cardamomum essential oils from this study are showed in Table 2. The results showed that the A. Cardamomum leaves oil had specific gravity value of between 0.903-0.909 while the $A$. Cardamomum rhizomes oils had specific gravity value of between $0.899-0.902$. The highest specific gravity were A.cardamomum oils distillated for 8 hours, both cardamom leaves oils and cardamom rhizomes oils. The value of specific gravity of $A$. cardamomum oils in this study probably influenced by the present of 1,8-cineol and $\mathrm{m}$ cymene compounds with specific gravity 0.922 and 0.861 , respectively (Haynes 2014). Refractive index of $A$. cardamomum leaves and rhizomes olis had value of 1.476-
1.478. Cardamom leaves oil which had the highest refractive index value is cardamom oil distilled for 6 hours, while the cardamom rhizomes oil having the highest refractive index is cardamom oil obtained for 8 hours distillation. A. cardamomum leaves oils had optical rotation value in average between $(+) 2.05^{\circ}-(+) 2.37^{\circ}$. While the cardamom rhizomes oils had optical rotation value in average between $(+) 2.24^{\circ}-(+) 2.38^{\circ}$. The optical rotation value of cardamom oils obtained in this study is lower than the standard by ISO 4733:1981. It probably due to this study used $A$. cardamomum while ISO 4733: 1981 is the standard for cardamom essential oil of Ellettaria cardamomum. This study used ISO standard because there is no standard for local cardamom of $A$. cardamomum. The results of the miscibility in $70 \%$ alcohol showed that the miscibility of $A$. cardamomum oils in alcohol were generally similar to the 
ratio of $1: 7$ to $1: 9$ with an average miscibility of $1: 8$. Miscibility of oil is influenced by the rapidity of oil solubility and the oils quality. If the oil mostly contained by oxygenated components, it will easily to be dissolved in alcohol (Guenther 1987). According to Ketaren (1985), the longer the amount of carbon chain, the more difficult the oil to be dissolved. The $A$. cardamomum leaves oils had an average acid number of 0.50-0.57 while $A$. cardamomum rhizomes oils had an average acid number of 0.49-0.69. The acid number in this study increased with the length of distillation time. The longer distillation time, water and oil contact is also longer and heat causes ester hydrolysis process to increase. Alcohol compounds with high molecules will be oxidized to aldehydes, carboxylic acids, and ketones.

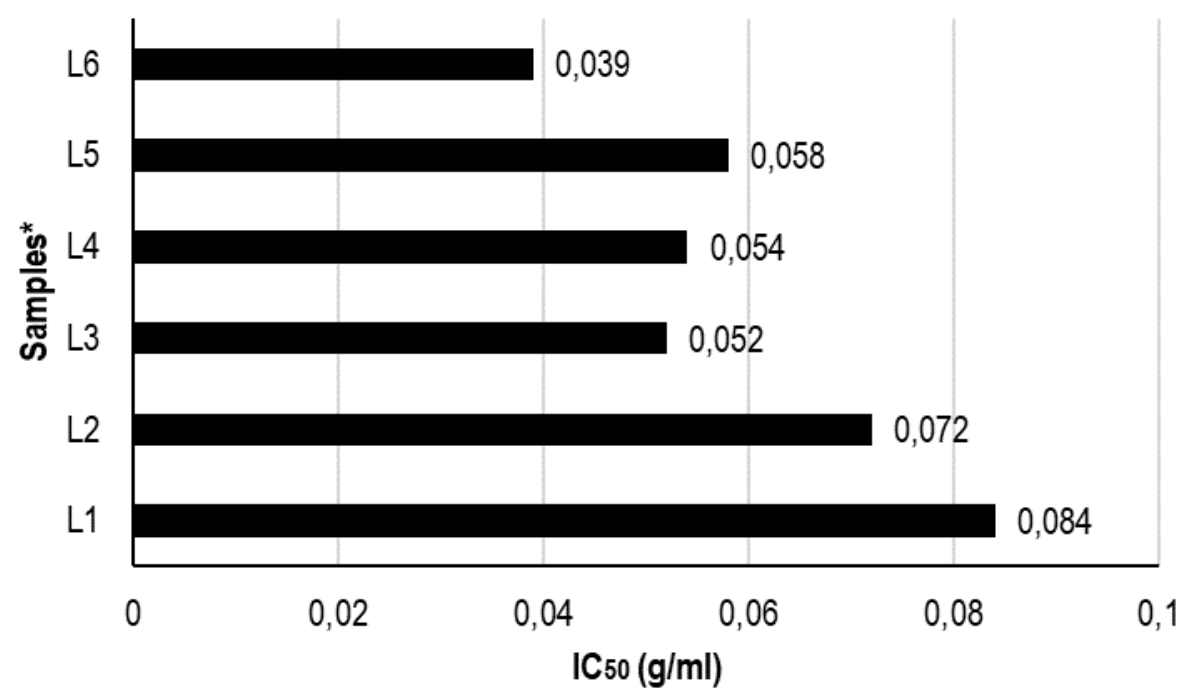

Figure 1. I $\mathrm{C}_{50}$ of $A$. cardamomum Leaves and Rhizomes Essential Oils (L1: Leaves oil-distillated for 4 hours, L2: Leaves oildistillated for 6 hours, L3: Leaves oil-distillated for 8 hours, L4: Rhizomes oil-distillated for 4 hours, L5: Rhizomes oil-distillated for 6 hours, L6: Rhizomes oil-distillated for 6 hours)

This study also tested the antioxidant activity of essential oils which was analyzed by DPPH method. The result showed that the antioxidant activities of $A$. cardamomum oils have tendency increase by increasing the concentration. The concentration of $0.05 \mathrm{~g} / \mathrm{ml}, 0.1 \mathrm{~g} / \mathrm{ml}, 0.15$ $\mathrm{g} / \mathrm{ml}, 0.2 \mathrm{~g} / \mathrm{ml}$ of $A$. cardamomum oils in this study have inhibitory concentration between 40.53 - 57.34\%, 52.10 $65.90 \%, 59.86-78.64 \%, 71.26$ - $86.5 \%$, respectively. Previous study also gave value of antioxidant activity increase by increasing concentration of essential oils (Pujiarti et al. 2015). Overall, A. cardamomum oils in this study have mild antioxidant activity. $I C_{50}$ values in each of cardamom oil are presented in Figure 1. The lower $I_{50}$ value had better antioxidant activity, because in small percentages. The antioxidant compound can prevent about $50 \%$ radical activity. The highest $\mathrm{IC}_{50}$ value of antioxidant activity was found in cardamom leaves oils distillated for 4 hours, while the lowest $\mathrm{IC}_{50}$ value of antioxidant activity was found in cardamom rhizomes distillated for 8 hours. The results of chemical analysis of cardamom oil obtained in this study showed that most of the chemical components in $A$. cardamomum oils consists of terpenoid groups from the monoterpenes group, oxygenated monoterpenes, sesquiterpenes and oxygenated sesquiterpenes with the largest percentage is the oxygenated monoterpenes.
Alkaloids and terpenoids from medicinal plants extraction have antioxidant activity when are tested with DPPH (Awouafack et al. 2013). Antioxidant activity of leaves and rhizomes oils in this study probably caused by the terpenoid contained in these oils such as m-cymene, patchoulene, and others terpenoid compounds. This study also found that average of antioxidant activity of cardamom leaves oils smaller than cardamom rhizomes oils. This is probably due to rhizomes oils have more terpenoid compound such as alpha thujene, linalool, and alpha-terpineol where are not found in leaves oils.

\section{Conclusions}

Leaves oils of $A$. cardamomum have higher yield than rhizomes oils. Distillation time had an effect on chemical compound of leaves and rhizomes oils of $A$. cardamomum, in which the chemical components of the oils were varied with the main compound was 1,8 cineole. However, distillation times had no effect on oils physico-chemical properties. A cardamomum leaves and rhizomes oils obtained from hydrodistillation 4,6, and 8 hours had same qulities. Leaves and rhizomes oils of $A$. cardamomum posses mild antioxidant, while the highest antioxidant 
activity obtained from rhizomes oils were distillated for 8 hours.

\section{References}

Ahn, C.; M.J. Park; J.W. Kim; J. Yang; S.S. Lee; E.B. Jeung. 2018. Cytotoxic Evaluation of Plant Essential Oils in Human Skin and Lung Cells. Journal of the Korean Wood Science and Technology 46(2): 166-177.

Anonymous. 1981. Oil of cardamomum. ISO 4733:1981. International Organization for Standardization

Awouafack, M.D.; P. Tane; N.E. Jacobus. 2013. Two New Antioxidant Flavones from The Twigs of Eriosema robustum (Fabaceae). Journal of Phytochemical Society of Europe 6(1): 62-66.

Batubara, I.; W.T. Wahyuni; M. Susanta. 2016a. Antibacterial Activity of Zingiberaceae Leaves Essential Oil Againts Streptococcus mutans and Teeth-Biofilm Degradation. International Journal of Pharma and Bio Science 7(4): 111-116.

Batubara, I.; U. Zahra; K.D. Latifah; A. Maddu. 2016b. Essential Oils of Zingiberaceae Leaves as Antioxidant and Antibacterial. Indonesian Journal of Essential Oil 1(1): 44-51.

Bozin, B.; M. Neda; N. Simin; G. Anackov. 2006. Characterization of the Volatile Composition of Essential Oils of Some Lamiaceae Spices and the Antimicrobial and Antioxidant Activities of the Entire Oils. Journal of Agricultural and Food Chemistry 54: 1822-1828.

Charles; J. Denys. 2013. Antioxidant Properties of Spices, Herbs and Other Sources. New York: Springer-Verlag New York.

Guenther, E. 1987. Essential Oil. Translated by R.S. Ketaren and R. Mulyono. Jakarta: Pres UI.

Haynes; M. William. 2014. CRC Handbook of Chemistry and Physics. 94th Edition.Boca Raton: CRC Press LLC.

Jaafar, F.M.; C.P. Osman; N.H. Ismail; K. Awang. 2007. Analysis of Essential Oils of Leaves, Stems, Flowers and Rhizomes of Etlingera elatior (Jack) R. M. Smith. Malaysian Journal of Analytical Sciences 11(1): 269273.

Ketaren. 1985. Introduction of Essential Oils Technology. Jakarta: Balai Pustaka Press.

Lim, T.K. 2013. Edible Medicinal and Non-Medicinal Plants: Volume 5, Fruits. Dordrecht: Springer Netherlands.

Molyneux, P. 2004. The Use of Stable Free Radical Diphenylpicryl-hydrazyl (DPPH) for Estimating Antioxidant Activity. Songklanakarin Journal of Science and Technology 26(2): 211-219.
Perricone, M.; E. Arace; M.R. Corbo; M. Sinigaglia; A. Bevilacqua. 2015. Bioactivity of Essential Oils: A Review on their Interaction with Food Components. Frontiers in Microbiology 6 (76): 1-7.

Pujiarti, R.; T.B. Widowati; Kasmudjo; S. Sunarta. 2015. Quality, Chemical Composition, and Antioxidative Activity of Cananga (Cananga odorata) Oil (In Indonesian). Jurnal IImu Kehutanan 9(1): 3-11.

Riendyani, V.K. 2014. Genetic Differences Identify and Compound Content of Cardamom (Red and White $A$. cardamomum) (In Indonesian). Thesis. Faculty of Mathematics and Natural Science, Department of Biochemistry, Bogor Agricultural Institute, Bogor.

Rosjidi, I. 1993. Effect of Freshness, Material Size and Distillation Time of the Quality and Yield of Local Cardamom Oil (A. cardamomum Willd.) (In Indonesian). Thesis. Department of Agricultural Industrial Technology, Faculty of Agricultural Technology, Bogor Agricultural University. Bogor.

Shaaban, H.A.; A.H. El-Ghorab; T. Shibamoto. 2011. Bioactivity of Essential Oils and their Volatile Aroma Components: Review. The Journal of Essential Oil Research 24(2): 203-212.

Sharma, R.; J. Xu; G. Sharma. 2007. Traditional Agroforestry in The Easter Himalaya Region: Land Management System Supporting Ecosystem Services. Tropical Ecology 48(2): 1-12.

Suryadinata, C. 2008. The Extraction of Cardamom Essential Oil (Amomum cardamomum) by Thin Layer Chromatography and Its Activity Against Malassezia furfur in Vitro. (In Indonesian). Thesis. Faculty of Medicine. Diponegoro University, Semarang.

Tepe, B.; D. Deferera; A. Sokmen; M. Sokmen; M. Polissiou 2005. Antimicrobial and Antioxidant Activities of the Essential Oil and Various Extracts of Salvia tomentosa Miller (Lamiaceae). Food Chemistry 90 (3): 333-340.

Wang, H.F.; K.H. Yih; C.H. Yang; K.F. Huang. 2017. Antioxidant Activity and Major Chemical Component Analyses of Twenty-Six Commercially Available Essential Oils. Journal of Food and Drug Analysis 25(9): 1-9.

Winarsi, H. 2014. Antioxidant of Amomum Leaf (In Indonesian). Yogyakarta: Graha IImu.

Rini Pujiarti and Aisyah Kusumadewi

Department of Forest Product Technology,

Faculty of Forestry, Universitas Gadjah Mada

Jl. Agro, No.01, Bulaksumur, Yogyakarta, 55281, Indonesia.

Phone/Fax :+62-274-550541

*E-mail : : rpujiarti@ugm.ac.id 